\title{
A preliminary study of the prevalence of post-traumatic stress disorder, depression and anxiety symptoms in female adolescents maltreatment victims in Mexico
}

\author{
Lucía Ester Rizo Martínez, Miguel Ángel Guevara Pérez, ${ }^{2}$ Marisela Hernández González, ${ }^{2}$ Juan José Sánchez Sosa ${ }^{3}$
}

Departamento de Promoción, Preservación y Desarrollo de la Salud, Centro Universitario del Sur, Universidad de Guadalajara, Ciudad Guzmán, Jalisco, México.

2 Instituto de Neurociencias, CUCBA, Universidad de Guadalajara, Guadalajara, Jalisco, México.

3 Coordinación de Posgrado en Psicología, Universidad Nacional Autónoma de México, Ciudad de México, México.

\section{Correspondence:}

Lucía Ester Rizo Martínez

Departamento de Promoción, Preservación y Desarrollo de la Salud, Centro Universitario del Sur, Universidad de Guadalajara.

Av. Enrique Arreola Silva No. 883,

Col. Centro, C.P. 49000, Ciudad

Guzmán, Jalisco, México.

Phone: +52 (341) 575 2222, Ext. 46168

Email: lucyrizomar@hotmail.com

Received: 15 Marzo 2018

Accepted: 16 Mayo 2018

\section{Citation:}

Rizo Martínez, L. E., Guevara Pérez, M. A., Hernández González, M., Sánchez Sosa, J. J. A preliminary study of the prevalence of post-traumatic stress disorder, depression and anxiety symptoms in female adolescents maltreatment victims in Mexico. Salud Mental, 47 (3), 139-144. doi: 10.17711/SM.0185-3325.2018.018

\section{(c) (i) (5)}

\begin{abstract}
Introduction. Although child maltreatment is related with psychopathologic symptoms, however their clinical prevalence in the general population and more so in specific groups of age and gender, such as female adolescents, has been scarcely documented. Objective. The purpose of the present study was to examine the prevalence mental illness symptoms -such as post-traumatic stress disorder, depression, and anxiety- in female adolescent maltreatment victims in Mexico. Method. Fifty-five 12-17-year old female adolescent victims of maltreatment (sexual, physical, and emotional abuse) recruited from four different Mexican institutions were evaluated through clinical scales for post-traumatic stress, depression, and anxiety, in addition to clinical interviews. Results. More than half of the participants presented significant scores of psychopathological symptoms in the three scales evaluated. Discussion and conclusion. The high prevalence of psychopathologic symptoms found in this study suggests that female adolescents who had experienced some form of abuse present highed a susceptibility to develop psychopathology. Results are discussed in the context of their relevance as a public health problem and their implications for professional interventions.
\end{abstract}

Keywords: Maltreatment, female adolescents, post-traumatic stress disorder, depression, anxiety.

\section{RESUMEN}

Introducción. Aunque el maltrato infantil se ha asociado con síntomas psicopatológicos, se ha documentado poco la prevalencia clínica que tiene en la población general y aún más en grupos específicos de edad y género, como en el caso de mujeres adolescentes. Objetivo. El presente estudio tiene como propósito examinar la prevalencia de síntomas de enfermedades mentales como el trastorno de estrés postraumático, la depresión y la ansiedad en adolescentes víctimas de maltrato en México. Método. Se evaluaron 55 mujeres adolescentes víctimas de maltrato (abuso sexual, físico y emocional) de 12 a 17 años, reclutadas en cuatro diferentes instituciones mexicanas. A todas se les aplicaron entrevistas y escalas clínicas de estrés postraumático, depresión y ansiedad. Resultados. Más de la mitad de las participantes presentaron altos puntajes de síntomas psicopatológicos en las tres escalas evaluadas. Discusión y conclusión. La alta prevalencia de síntomas psicopatológicos encontrada en este estudio sugiere que las adolescentes que experimentaron alguna forma de abuso presentaron una alta susceptibilidad a desarrollar psicopatología. Se discuten los resultados en el contexto de su relevancia como un problema de salud pública y sus implicaciones para las intervenciones profesionales correspondientes.

Palabras clave: Maltrato, mujeres adolescentes, trastorno por estrés postraumático, depresión, ansiedad. 


\section{INTRODUCTION}

Child maltreatment can be defined as all forms of physical and/or emotional ill-treatment, sexual abuse, neglect, negligent treatment, and commercial or other exploitation resulting in actual or potential harm to a child's health, survival, development, or dignity in the context of a relationship or responsibility of trust or power (World Health Organization, 1999).

As regards the global prevalence of child maltreatment, an estimated 57000 deaths were attributed to the homicide of children less than 15 years of age in the year 2000 , with rates highest amongst infants and very young children (0-4 years) (Krug, Mercy, Dahlberg, \& Zwi, 2002). According to the United Nations Children's Fund (2006), Mexico occupies one of the first places in physical violence, sexual abuse, and homicide of children less than 14 years, with abuse being perpetrated mainly by parents. Also, the Encuesta Nacional sobre la Dinámica de las Familias en México (2011) reports that many children grow amidst violence and maltreatment on the part of their parents in nearly 13 million families.

Many children suffer severe detrimental consequences because of maltreatment which can last well into late adolescence and adulthood. Several worldwide studies suggest that early in life adverse experiences, such as child abuse, result in developmental changes at various levels; for example, in the main biological stress modulating systems (Browne \& Finkelhor, 1986; Teicher et al., 2003), as well as changes in the brain both anatomically (Andersen et al., 2008) and functionally (Ito, Teicher, Glod, \& Ackerman, 1998). The above findings have been linked to the development of mood disorders such as depression, anxiety, dissociation, behavioral disorders, aggressiveness, inappropriate or abnormally precocious sexual behavior, loss of self-esteem, prostitution, delinquent behavior, suicide (attempted or consummated), and post-traumatic stress disorder (PTSD) symptoms (Bagley \& Shewchuk-Dann, 1991; Conte \& Schuerman, 1987; Caffaro-Rouget, Lang, \& Van Santen, 1989; Paolucci, Genuis, \& Violato, 2001; Kiser, Heston, Millsap, \& Pruitt, 1991; López-Soler et al., 2012). It has even been shown that early onset abuse in childhood is associated with an earlier onset of psychopathology (Leverich et al., 2002).

However, it has also been reported that there are several factors to consider when evaluating the consequences of abuse. For example, some research have reported gender differences in the exposure to traumatic events and it was found too that rape or other types of sexual assault were higher in women than in men, while assaultive violence, accidents, and witnessing violence were higher in men than in women. It has been reported that specific types of traumatic events are associated with the occurrence of psychopathological symptoms (Cuffe et al., 1998; Norris, 1992; Breslau et al., 1998).
Despite the high prevalence of child maltreatment in Mexico, studies regarding its short- and long-term clinical effects are scarce. Among these, Medina-Mora et al. (2005) conducted a study in a Mexican urban population aged 18 to 65 and they found that, like other studies, the exposure to different violent events varied by sex and by age. Also, they reported that $2.3 \%$ of women and $.49 \%$ of men presented PTSD. Other important contribution of this study is that it was found that rape, harassment, kidnapping, and sexual abuse are the events most associated with PTSD. In the same way, Baker et al. (2005) examined the lifetime prevalence of violence and PTSD in four cities in Mexico. In their study, they found gender differences with respect to the exposure to violent events and that, of those exposed, only $11.5 \%$ presented PTSD. They also reported that probabilities were highest after sexual and intimate partner violence, and higher for women than men. Meanwhile Orozco, Borges, Benjet, Medina-Mora, and López-Carrillo (2008) studied an adolescent population in Mexico City; the prevalence of traumatic life events and PTSD were estimated. Most of the adolescents reported at least one traumatic event in their lifetimes and there were also differences by sex; the general prevalence for PTSD were $1.8 \%$ and sexual-related traumas were also most associated with PTSD.

The purpose of the present study was to examine the prevalence of the most frequent mental illnesses in the general population, such as depression and anxiety, and relate them to the consequences of abuse, such as PTSD, in Mexican female adolescent victims of maltreatment. To achieve this, the following premises were considered: a) according to the World Health Organization (2017), depression and anxiety are two of the most frequent mental disorders in the general population ( $7.5 \%$ and $3.4 \%$, respectively); b) PTSD is a clinical condition that represents a psychic response to a traumatic event and was incorporated as such in the international psychiatric diagnostic classifications several years ago; c) adolescence is a very sensitive stage of life for both the exposure to various types of abuse and the presence of psychopathological symptoms.

\section{METHOD}

\section{Participants}

A total of 55 female adolescents victims of maltreatment (sexual, physical, and emotional) were recruited from three orphanages and from the Multidisciplinary Group of Attention to Maltreatment Victims Unit of the Hospital Civil Juan I. Menchaca in Jalisco, Mexico. A non-probabilistic sampling of intentional type was used. Participants were selected if they had a confirmed history of child maltreatment according to the files from their respective institutions and they were recruited and evaluated during the period from 
2012 to 2016 . The inclusion criteria were the following: 1217-year old female adolescents without neurological problems or chronic diseases, who showed a confirmed history of maltreatment during childhood. The exclusion criterion was that the participants did not complete the evaluation. The general data are summarized in Table 1.

\section{Instruments}

All the adolescent and their parents or advisors were administered a semi-structured interview. In addition, the files of each adolescent were reviewed at the institutions to which they belonged to or attended at the time this study was carried out. Each participant was evaluated using the following clinical scales:

Children's Post-Traumatic Stress Scale (CPSS) (Foa, Johnson, Feeny, \& Treadwell, 2001). The CPSS evaluates the presence of symptoms of post-traumatic stress disorder in children and adolescents from eight to 18 years of age with a known history of trauma, and it is based on the diagnostic criteria of the DSM-IV. The CPSS is composed of 17 items with a Likert-type response referring to the frequency of manifestation of symptoms of this disorder and consists of three subscales: Reexperimentation (five items), Avoidance (seven items), and Increase of Activation (five items) (Foa et al., 2001). A score $\geq$ to 11 on the full scale indicates mild symptomatology. A score $\geq 18$ on the full scale indicates moderate to severe symptomatology. The scores provide the severity of the trauma for each of the three symptomatic groups (reexperimentation, avoidance, and activation). The results can be linked to the evaluation of emotional damage. The original version of the CPSS indicates acceptable levels of reliability due to internal consistency, presenting Cronbach's alpha coefficients of .89 for the full scale. For this study, the Spanish

Table 1

General characteristics of the participants and the experience of abuse

\begin{tabular}{lcc}
\hline Total sample $(n=55)$ & Ages in years: $M=13.88 \%$ & $S D=3.53$ \\
\hline Typeof abuse & Frequency & Percentage $(\%)$ \\
\hline Socioeconomic status: lower class & & \\
$\quad$ Sexual & 34 & 61.81 \\
Physical & 13 & 23.63 \\
Emotional & 8 & 14.54 \\
Relationship with the aggressor & & \\
Parents & 38 & 69.09 \\
Stepfather & 10 & 18.18 \\
Grandfather & 5 & 9.09 \\
Strangers & 2 & 3.63 \\
Institution & & \\
Orphanage 1 & 13 & 23.63 \\
Orphanage 2 & 15 & 27.27 \\
Orphanage 3 & 6 & 10.90 \\
Civilian Hospital & 11 & 20.00 \\
\hline
\end{tabular}

version by Bustos, Rincón, and Aedo (2009) was used and it shows a Cronbach alpha coefficient of .916 for the full scale. The best combination of sensitivity and specificity was obtained considering the $23 / 24$ value as a cut score. The sensitivity corresponds to $82 \%$ and the specificity to $88 \%$. The degree of total agreement is $88 \%$, with a positive predictive value of $45 \%$ and a negative predictive value of $98 \%$.

Children's Depression Inventory (CDI) (Kovacs, 1983). This instrument was designed to measure depressive symptomatology in children and adolescents. The version validated in Spanish consists of 27 items, each of them expressed in three sentences that show the depressive symptomatology in different intensities or frequencies. The questions are scored from $0-2$. Results from the test allowed for the collection of data on total depression and two additional scales: dysphoria and negative self-esteem. The total score may range between 0 and 54 points. The cut-off point is 19 , so depression is presented from that score. The test presents a sensitivity of $94.7 \%$, its specificity is $95.6 \%$, and it has a positive predictive value of .90 and a negative predictive value of .98 (Figueras, Amador-Campos, Gómez-Benito, \& del Barrio, 2010). It presents a Cronbach's alpha coefficient between .70 and .94 in normal and clinical samples. We used the Spanish version made by del Barrio and Carrasco (2004) which presents a Cronbach's alpha coefficient of .79.

State-Trait Anxiety Inventory for Children (STAIC) (Spielberg, Gorsuch, \& Lushene, 1970). The State-Trait Anxiety Inventory (STAIC), created by Spielberger et al. (1970), is preceded by the STAI test, by the same author. The STAIC test is applied to children and adolescents between 9 and 15 years of age. It is intended to specifically measure the anxiety factor, and offers two evaluations for it with 20 items each: anxiety state and anxiety trait. The child must indicate the degree to which he/she presents these feelings on a scale from 1 to 3: 1- nothing, 2- something, and 3- much. The score for each scale may range from 0-30, where higher scores, indicate higher levels of anxiety. It has been reported that the optimal value for faces scale score was 4 , with a sensitivity of .61 (95\% CI [.59, $.62])$ and a specificity of $.82(95 \%$ CI $[.81, .83])$. When this threshold was applied to the construction and validation cohorts, $61.3 \%$ and $44.4 \%$ of the positives were true positives in the construction and validation cohorts, respectively; and $82.1 \%$ and $81.3 \%$ of the negatives were true negatives, respectively (Bellon et al., 2017). For this study, a Spanish version carried out by Castrillón and Borrero (2005) was used which presents a Cronbach alpha of .70.

\section{Procedure}

We visited different institutions such as orphanages and a civil hospital to ask their authorities if adolescents with a 
history of abuse could participate in this study. Institutions that could be useful for the study and those interested in it were selected. Information about the present investigation was given, doubts were clarified, and advice was offered regarding the results of the study, together with information about the institutions that could offer follow-up services of various types. Participants presented experiences of abuse which were confirmed by reviewing files kept at the institutions involved (the hospital or orphanages). Based on these reviews and through the clarification of doubts by the corresponding authorities or tutors, participants were classified according to the main type of abuse experienced.

Once the participants were selected, each one was given an informed consent letter to sign and the corresponding doubts were once again clarified. Then an evaluation was made, which included the application of post-traumatic stress, depression, and anxiety scales, which were applied by the first author of this article at the institutions to which the adolescents lived in or attended. Individual sessions lasted for approximately 40 minutes. None of the participants had previously been evaluated with these clinical scales.

\section{Ethical considerations}

All procedures involved in this experiment were approved by the Ethics Committee of the Instituto de Neurociencias of the Universidad de Guadalajara (Guadalajara, Jalisco, México) in accordance with the ethical standards established in the 1964 Helsinki Declaration. All participants and their parents or guardians gave their informed consent prior to their inclusion.

\section{Statistical analyses}

The prevalence of childhood PTSD, depression, and anxiety was calculated for each type of abuse according to the standards and scores of each of the tests used, once the information was gathered, collected databases in Excel (Microsoft) were created. A non-parametric statistical analysis with SPSS 15.0 for Windows was carried out for the frequency and percentage of the general characteristics and scores of the scales for each group.

\section{RESULTS}

In this study, it was observed that the duration of maltreatment did not affect the presence or absence of symptoms, which was corroborated through a descriptive analysis of the data. In most cases, the abuse was perpetrated by relatives like the parents, a stepfather or a grandfather. Only in two cases was the maltreatment perpetrated by strangers.

In this study, almost half of the participating adolescents who had experienced sexual and emotional abuse and
Table 2

Summary of clinical test scores

\begin{tabular}{lccc}
\hline Type of maltreatment & & & \\
\hline Clinical scales & $\begin{array}{c}\text { Sexual } \\
(n=34)\end{array}$ & $\begin{array}{c}\text { Physical } \\
(n=13)\end{array}$ & $\begin{array}{c}\text { Emotional } \\
(n=8)\end{array}$ \\
\hline Children's Post-Traumatic & & & \\
Stress Scale (CPSS) & & & \\
$\quad$ Frecuency & $28\left(8 \mathrm{~S}^{*}\right)$ & $12\left(2 \mathrm{~S}^{*}\right)$ & $6\left(1 \mathrm{~S}^{*}\right)$ \\
$\quad$ Percentage \% & 82.35 & 91.66 & 75 \\
Children's depression & & & \\
Inventory (CDI) & & & \\
$\quad$ Frecuency & 17 & 8 & 4 \\
$\quad$ Percentage \% & 50 & 58.33 & 50 \\
State-Trait Anxiety Inventory & & & \\
for Children (STAIC) & & & \\
$\quad$ Frecuency & 20 & 8 & 5 \\
Percentage \% & 58.82 & 58.33 & 62.50 \\
\hline
\end{tabular}

Note: $\mathrm{S}^{*}=$ Subsyndromal PTSD diagnosis present (at least 1 re-experiencing symptom, 3 of avoidance symptom or 2 of increased activation).

most of the adolescents who had experienced physical abuse revealed high scores of depression according to the standards considered for the CDI scale. In the same way, most participants also presented high scores of anxiety. With respect to the results of the CPSS scale, in the present study, only the two highest frequencies were considered to determine the presence or absence of PTSD or PTSD sub-syndromal (Frances, 1994) based on the diagnostic criteria of the DSM-IV since this scale is based on this manual. Most participants presented PTSD or PTSD sub-syndromal. Table 2 summarizes the main findings from the data analyses.

\section{DISCUSSION AND CONCLUSION}

The objective of this study was to evaluate the prevalence of PTSD, depression, and anxiety in female adolescents with previous experiences of abuse. In general, it was found that a high percentage of the adolescents evaluated presented PTSD or PTSD sub-syndromal, as well as high scores of depression and anxiety.

The psychopathological effects of child maltreatment in both the short- and long-term have been widely reported, including PTSD, depression, and anxiety (Kiser et al., 1991; Thompson, Kaslow, Lane, \& Kingree, 2000; Vranceanu, Hobfoll, \& Johnson, 2007; Kaufman, 1991; Toth, Manly, \& Cicchetti, 1992; Gibb et al., 2001; Stein, Schork, \& Gelernter, 2008; Hamilton et al., 2013; Kaplow \& Widom, 2007). However, most of these studies are performed in populations with a wide age range. In the present study, we examined the specific adolescence period and only on female participants.

Likewise, previous studies dealing with the psychopathologic effects of different types of child maltreatment have found lower rates of PTSD compared with this study 
(Widom, 1999; Deblinger, McLeer, Atkins, Ralphe, \& Foa, 1989; Famularo, Fenton, Kinscherff, \& Augustyn, 1996; Medina-Mora et al., 2005; Baker et al., 2005; Orozco et al., 2008). Also, a study made by López-Soler et al. (2012), which included 42 boys and girls aged six to 16 years, found only a low percentage of anxiety and depression symptoms. The results found in this study may be due to the wide of age range considered, which can be a key criterion, especially in the context of findings suggesting that the effects of abuse do not always appear in the short term, but are more likely to predict the development of psychiatric illnesses during adolescence (Giedd, Keshavan, \& Paus, 2008). The present study was conducted on adolescent females on the basis or reports that the prevalence of various forms of psychopathology, including depression and anxiety, increase during adolescence (Dahl, 2004).

The following are among limitations of this study. First, it would be useful to consider the evaluation of other psychiatric symptoms, such as sleep disorders, externalizing behaviors, dissociation, suicide ideation or attempt, sexual promiscuity, the victim-perpetrator cycle, etc. Second, this study used one clinical scale for each psychopathology and so other complementary clinical scales could be included to add replicability to the results. However, until now there are only few scales and validated in Spanish that evaluate psychopathological disorders in children so it is important to start to create and validate scales with good psychometric properties that complement correctly the accomplishment of diagnoses. For example, in this study, we used the STAIC scale, which, because it does not present adequate sensitivity indexes (.61), the ability to identify possible cases of anxiety is not ideal; however, this scale is one of the few validated in Latin American population and applied frequently in the diagnosis of anxiety in children. Third, it would be interesting to carry out a comparative study with males of the same age of the female adolescents in this study and examine psychopathological predominant features. Fourth, only a small sample of female adolescent maltreatment victims was recruited, so it is difficult to generalize the findings. However this study is still a very good index of the general problem.

This study represents one of the few attempts to determine the relationship between abuse and psychopathological disorders such as PTSD, depression, and anxiety during adolescence. The results presented in this paper could serve as a point of reference for planning and conducting studies that provide a more accurate picture of this phenomenon as well as for conducting studies aimed at prevention and intervention.

\section{Funding}

None.

\section{Conflict of interests}

The authors declare they have no conflict of interests.

\section{Acknowledgements}

The authors thank Dr. Javier Álvaro Barriga Marín, Chief of Emergency Pediatrics and Coordinator of the Multidisciplinary Group for Child Victims of Abuse at the Hospital Civil Dr. Juan I. Menchaca, Guadalajara, Jalisco, Mexico, for the facilities provided for the realization of this study and Dr. Felipe de Jesús Diaz Resendiz for the support provided in the review of this article.

\section{REFERENCES}

Andersen, S. L., Tomada, A., Vincow, E. S., Valente, E., Polcari, A., \& Teicher, M. H. (2008). Preliminary evidence for sensitive periods in the effect of childhood sexual abuse on regional brain development. The Journal of neuropsychiatry and clinical neurosciences, 20(3), 292-301.

Bagley, C. \& Shewchuk-Dann, D. (1991). Characteristics of 60 children and adolescents who have a history of sexual assault against others: Evidence from a controlled study. Journal of Child \& Youth Care, 43-52.

Baker, C. K., Norris, F. H., Diaz, D. M., Perilla, J. L., Murphy, A. D., \& Hill, E. G. (2005). Violence and PTSD in Mexico. Social psychiatry and psychiatric epidemiology, 40(7), 519-528. doi: 10.1007/s00127-005-0921-2

Bellon, M., Taillardat, E., Hörlin, A. L., Delivet, H., Brasher, C., Hilly, J., \& Dahmani, S. (2017). Validation of a simple tool for anxiety trait screening in children presenting for surgery. British Journal of Anaesthesia, 118(6), 910-917.

Breslau, N., Kessler, R. C., Chilcoat, H. D., Schultz, L. R., Davis, G. C., \& Andreski, P. (1998). Trauma and posttraumatic stress disorder in the community: the 1996 Detroit Area Survey of Trauma. Archives of general psychiatry, 55(7), 626-632. doi: 10.1001/archpsyc.55.7.626

Browne, A. \& Finkelhor, D. (1986). Impact of child sexual abuse: a review of the research. Psychological bulletin, 99(1), 66. doi: 10.1037/0033-2909.99.1.66

Bustos, P., Rincón, P., \& Aedo, J. (2009). Validación preliminar de la escala infantil de síntomas del trastorno de estrés postraumático (child PTSD symptom Scale, CPSS) en niños/as y adolescentes víctimas de violencia sexual. Psykhe (Santiago), 18(2), 113-126.

Caffaro-Rouget, A., Lang, R. A., \& Van Santen, V. (1989). The impact of child sexual abuse on victims' adjustment. Annals of sex research, 2(1), 29-47.doi:10.1007/ BF00850678

Castrillón, D. A. \& Borrero, P. E. (2005). Validación del inventario de ansiedad estado-rasgo (STAIC) en niños escolarizados entre los 8 y 15 años. Acta colombiana de psicología, 8(1), 79-90.

Conte, J. R. \& Schuerman, J. R. (1987). Factors associated with an increased impact of child sexual abuse. Child abuse \& neglect, 11(2), 201-211. doi: 10.1016/01452134(87)90059-7

Cuffe, S. P., Addy, C. L., Garrison, C. Z., Waller, J. L., Jackson, K. L., McKeown, R. E., \& Chilappagari, S. (1998). Prevalence of PTSD in a community sample of older adolescents. Journal of the American Academy of Child \& Adolescent Psychiatry, 37(2), 147-154. doi: 10.1097/00004583-199802000-00006

Dahl, R. E. (2004). Adolescent brain development: a period of vulnerabilities and opportunities. Keynote address. Annals of the New York Academy of Sciences, 1021(1), 1-22. doi: 10.1196/annals.1308.001

Deblinger, E., McLeer, S. V., Atkins, M. S., Ralphe, D., \& Foa, E. (1989). Post-traumatic stress in sexually abused, physically abused, and nonabused children. Child abuse \& neglect, 13(3), 403-408. doi: 10.1016/0145-2134(89)90080-X

Del Barrio, V., \& Carrasco, M. A. (2004). CDI. Inventario de depresión infantil. Madrid: TEA Ediciones.

Encuesta Nacional sobre la Dinámica de las Familias en México. (2011). Unidad de Estudios de la Opinión del Instituto de Investigaciones Sociales, UNAM. Retrieved from http://www.dif.gob.mx/diftransparencia/media/encuestanaldinamfamiliamex2011.pdf

Famularo, R., Fenton, T., Kinscherff, R., \& Augustyn, M. (1996). Psychiatric comorbidity in childhood post-traumatic stress disorder. Child abuse \& neglect, 20(10), 953-961.

Figueras, A., Amador-Campos, J. A., Gómez-Benito, J., \& Del Barrio, V. (2010). Psychometric Properties of the Children's Depression Inventory in Community 
and Clinical Sample. The Spanish Journal of Psychology, 13(2), 990-999. doi: $10.1017 / \mathrm{S} 1138741600002638$

Foa, E. B., Johnson, K. M., Feeny, N. C., \& Treadwell, K. R. (2001). The Child PTSD Symptom Scale: A preliminary examination of its psychometric properties. Journal of clinical child psychology, 30(3), 376-384. doi: 10.1207/ S15374424JCCP3003_9

Frances, A. (1994). Diagnostic and statistical manual of mental disorders: DSM-IV. American Psychiatric Association.

Gibb, B. E., Alloy, L. B., Abramson, L. Y., Rose, D. T., Whitehouse, W. G., Donovan, P., ... Tierney, S. (2001). History of childhood maltreatment, negative cognitive styles, and episodes of depression in adulthood. Cognitive Therapy and Research, 25(4), 425-446. doi: 10.1023/A:1005586519986

Giedd, J. N., Keshavan, M., \& Paus, T. (2008). Why do many psychiatric disorders emerge during adolescence?. Nature Reviews Neuroscience, 9(12), 947. doi: $10.1038 / \mathrm{nrn} 2513$

Hamilton, J. L., Shapero, B. G., Stange, J. P., Hamlat, E. J., Abramson, L. Y., \& Alloy, L. B. (2013). Emotional maltreatment, peer victimization, and depressive versus anxiety symptoms during adolescence: hopelessness as a mediator. Journal of Clinical Child \& Adolescent Psychology, 42(3), 332-347. doi: 10.1080/15374416.2013.777916

Ito, Y., Teicher, M. H., Glod, C. A., \& Ackerman, E. (1998). Preliminary evidence for aberrant cortical development in abused children: A quantitative EEG study. The Journal of neuropsychiatry and clinical neurosciences, 10(3), 298-307. doi: 10.1176/jnp. 10.3.298

Kaplow, J. B. \& Widom, C. S. (2007). Age of onset of child maltreatment predicts long-term mental health outcomes. Journal of abnormal Psychology, 116(1), 176. doi: $10.1037 / 0021-843 X .116 .1 .176$

Kaufman, J. (1991). Depressive disorders in maltreated children. Journal of the American Academy of Child \& Adolescent Psychiatry, 30(2), 257-265. doi: 10.1097/00004583-199103000-00014

Kiser, L. J., Heston, J., Millsap, P. A., \& Pruitt, D. B. (1991). Physical and sexual abuse in childhood: Relationship with post-traumatic stress disorder. Journal of the American Academy of Child \& Adolescent Psychiatry, 30(5), 776-783. doi: 10.1016/S0890-8567(10)80015-2

Kovacs, M. (1983). The children's depression inventory: A self-rated depression scale for school-aged youngsters. Pittsburgh: University of Pittsburgh School of Medicine.

Krug, E. G., Mercy, J. A., Dahlberg, L. L., \& Zwi, A. B. (2002). The world report on violence and health. The lancet, 360(9339), 1083-1088.

Leverich, G. S., McElroy, S. L., Suppes, T., Keck, P. E., Denicoff, K. D., Nolen, W. A., ... Autio, K. A. (2002). Early physical and sexual abuse associated with an adverse course of bipolar illness. Biological psychiatry, 51(4), 288-297. doi: 10.1016/S0006-3223(01)01239-2

López-Soler, C., Fernández, M. V., Prieto-Larrocha, M., Alcántara-López, M. V., Saéz, M. C., \& López-Pina, J. A. (2012). Prevalencia de las alteraciones emocionales en una muestra de menores maltratados. Anales de Psicología, 28(3), 780-788. doi: 10.6018/analesps.28.3.140441
Medina-Mora, M., Borges-Guimaraes, G., Lara, C., Ramos-Lira, L., Zambrano, J., \& Fleiz-Bautista, C. (2005). Prevalencia de sucesos violentos y de trastorno por estrés postraumático en la población mexicana. Salud pública de México, 47(1), 8-21. doi: $10.1590 / \mathrm{S} 0036-36342005000100004$

Norris, F. H. (1992). Epidemiology of trauma: frequency and impact of different potentially traumatic events on different demographic groups. Journal of consulting and clinical psychology, 60(3), 409.doi: 10.1037/0022-006X.60.3.409

Orozco, R., Borges, G., Benjet, C., Medina-Mora, M. E., \& López-Carrillo, L. (2008). Traumatic life events and posttraumatic stress disorder among Mexican adolescents: Results from a survey. Salud Pública de México, 50(s1), s29-s37. doi: 10.1590/S0036-36342008000700006

Paolucci, E. O., Genuis, M. L., \& Violato, C. (2001). A meta-analysis of the published research on the effects of child sexual abuse. The Journal of Psychology, 135(1), 17-36. doi: $10.1080 / 00223980109603677$

Spielberger, C. D., Gorsuch, R. L., \& Lushene, R. E. (1970). Manual for the state-trait anxiety inventory. Retrieved from http://hdl.handle.net/10477/2895

Stein, M. B., Schork, N. J., \& Gelernter, J. (2008). Gene-by-environment (serotonin transporter and childhood maltreatment) interaction for anxiety sensitivity, an intermediate phenotype for anxiety disorders. Neuropsychopharmacology, 33(2), 312-319. doi: 10.1038/sj.npp. 1301422

Teicher, M. H., Andersen, S. L., Polcari, A., Anderson, C. M., Navalta, C. P., \& Kim, D. M. (2003). The neurobiological consequences of early stress and childhood maltreatment. Neuroscience \& Biobehavioral Reviews, 27(1), 33-44. doi: 10.1016/S0149-7634(03)00007-1

Thompson, M. P., Kaslow, N. J., Lane, D. B., \& Kingree, J. B. (2000). Childhood maltreatment, PTSD, and suicidal behavior among African American females. Journal of Interpersonal Violence, 15(1), 3-15.

Toth, S. L., Manly, J. T., \& Cicchetti, D. (1992). Child maltreatment and vulnerability to depression. Development and Psychopathology, 4(1), 97-112. doi: 10.1017/ S0954579400005587

United Nations Children's Fund. (2006). Compilación de observaciones finales del Comité de los Derechos del Niño sobre países de América Latina y el Caribe (1993-2006). Retrieved from https://www.unicef.org/cuba/Compilacion_de_ observaciones_finales_del_comite_sobre_los_derechos_del_nino_sobre_paises_de_America_Latina_y_el_Caribe.pdf

Vranceanu, A. M., Hobfoll, S. E., \& Johnson, R. J. (2007). Child multi-type maltreatment and associated depression and PTSD symptoms: The role of social support and stress. Child abuse \& neglect, 31(1), 71-84. doi: 10.1016/j.chiabu. 2006.04 .010

Widom, C. S. (1999). Posttraumatic stress disorder in abused and neglected children grown up. American Journal of Psychiatry, 156(8), 1223-1229. doi: 10.1176/ ajp.156.8.1223

World Health Organization. (1999). Report of the Consultation on Child Abuse Prevention, 29-31 March 1999.Geneva: World Health Organization.

World Health Organization. (2017). Depression and other common mental disorders: global health estimates. Geneva: World Health Organization. 